\title{
Familiantský zákon a jeho dopad na proces udělování svatebních konsensů v Čechách
}

\author{
Ivana Ebelová / ivana.ebelova@ff.cuni.cz \\ Katedra pomocných věd historických a archivního studia, Filozofická fakulta, Univerzita Karlova
}

\begin{abstract}
The paper is devoted to the application processing procedure for granting wedding permission to the Jewish population after the introduction of the Familiant Law of 1726. The study concentrates on the written material of the administration with the competence for Bohemia. The agenda was in the competence of the Jewish Commission that was established in 1714 in connection with attempts to restrict the Jewish population. The issuance of the Familiant Law was accompanied by a number of measures, which were reflected in the written production not only of the Jewish Commission but of other offices as well. Examples of these documents and those directly related to the processing of applications for wedding permission, from submission to conclusion, document the whole process of implementing the law and the practical course of the approval procedure.
\end{abstract}

\section{Keywords}

Jews, Jewish Commission, Familiant Law, familiant, incolat, early modern period, family, translocation rescript, marriages, wedding permission, inventories, regional authorities, manorial nobility authorities, patent, decree, regulations.

Tato studie vznikla na Univerzitě Karlově v rámci programu PROGRES Q09: Historie - Klíč k pochopení globalizovaného světa. 


\section{Úvodem}

Příspěvek do určité míry navazuje na text zaměřený na vznik židovské komise (Commissio in rebus judeorum), ${ }^{1}$ její kompetence, náplň činnosti a především pak na základní typy písemností související, respektive vycházející z její působnosti, jenž byl prezentován na podzim roku 2016 na konferenci Formy a premeny diplomatickej produkcie v novoveku, pořádané Katedrou archívnictva a PVH Univerzity Komenského v Bratislavě. ${ }^{2}$ V dané souvislosti je na místě alespoň stručné připomenutí hlavního úkolu nově zřízené komise, spočívajícího ve své původní podobě v zásadní redukci počtu židovských obyvatel ve městech i na venkově. Tento záměr však v dané podobě záhy ztroskotal, a to především s ohledem na fiskální zájmy komory. Rozsah činnosti komise (jejíž působnost a kompetence se vztahovala pouze na Čechy) byl postupně redukován, zvláště po vydání familiantského zákona v roce 1726 (viz níže). Do kompetence komise tak poté spadala zejména evidence a kontrola dodržování počtu familiantských míst, projednávaní záležitostí týkajících se udílení inkolátu, udělování svatebních konsensů, ale i záležitostí neofytů. Své místo měla komise, respektive její členové, při řešení záležitostí ekonomického charakteru, především pak otázek daňových.

$\mathrm{Z}$ naznačené původní poměrně široké škály otázek, jejichž projednáváním byli pověřeni členové komise, byla pro předkládaný text zvolena oblast týkající se procesu udílení svatebních konsensů od podání konkrétní žádosti až po její vyřízení, zvláště jednotlivým typům písemností souvisejících určitým způsobem s naplněním litery familiantského zákona a vážících se $\mathrm{k}$ agendě udílení souhlasu s uzavřením sňatku.

\section{Familiantský zákon}

Stěžejním ustanovením, bezprostředně ovlivňujícím život židovského obyvatelstva v Českých zemích, byl od dvacátých let 18. století (konkrétně od roku 1726) až do roku 1848 tzv. familiantský zákon, následovaný v roce 1727 vydáním tzv. translokačního reskriptu.

Zatímco hlavním cílem familiantského zákona byla snaha zastavit a zásadním způsobem snížit stávající počet židovského obyvatelstva v Českých zemích, ideálně na stav z roku 1618 (viz níže), translokačním reskriptem byla přesně vymezena místa jeho budoucího pobytu a stanoveny jednotlivé podmínky, jimiž byla podmiňována možnost pobytu židů v konkrétní lokalitě. Především nesměli nadále bydlet mezi křestanským obyvatelstvem, což v důsledku znamenalo, že se museli přestěhovat do vymezených čtvrtí (ghett), ulic či jednotlivých domů, oddělených od obydlí většinového křestanského obyvatelstva. Zásadní bylo v této souvislosti ustanovení, aby židovské obyvatelstvo pobývalo v domech situovaných v dostatečné vzdálenosti od kostelů či míst, jimiž procházela v době křestanských svátků církevní procesí, ve snaze předejít v maximální možné míre potenciálním

1 Komise byla zřízena 8. ledna 1714 reskriptem Karla VI. při českém místodržitelství a české komoře. Písemnosti z její činnosti jsou uloženy v Národním archivu (dále NA).

2 Ebelová, Ivana: Commissio in rebus Judaeorum a její písemnosti, in: Formy a premeny diplomatickej produkcie v novoveku I. Edd. Šedivý Juraj - Való Ján. Bratislava 2018, s. 81-100. 


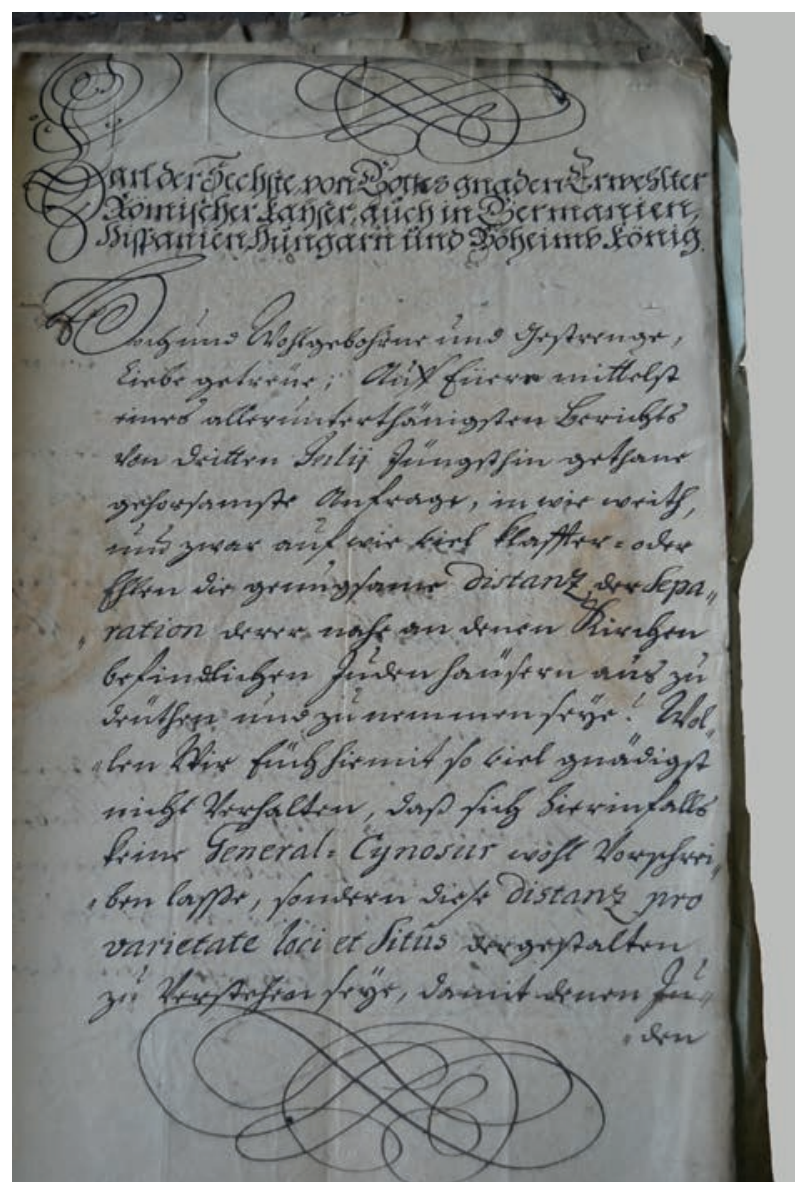

Obr. 1: Translokační reskript Karla VI. z roku 1727 (NA, SM, sg. J 4 43.)

vzájemným konfliktům. ${ }^{3}$ Podle hrubého odhadu se nařízení týkalo asi 30000 českých židů, usazených v té době v 840 městech a vesnicích a 20000 židů moravských. ${ }^{4}$

Vydání translokačního reskriptu a jeho dopady na strukturu židovského osídlení v Českých zemích ponechejme však v dané souvislosti stranou, byṫ se jedná o téma, které si zaslouží samostatnou pozornost, ${ }^{5}$ a vratme se zpět k vlastnímu familiantskému zákonu.

3 Translokační reskript dopadal nejen na židovské, ale i většinové křestanské obyvatelstvo. Velmi konkrétně o praktických důsledcích jeho zavedení informuje mezi jinými zpráva olomouckého biskupa z 6 . května 1727, podle níž měli být v př́padě potřeby přestěhováni tito naopak do židovských domů. Pokud nebylo přestěhování obyvatelstva at̉ z jedné či druhé strany reálné, měly být odděleny židovské čtvrti či domy postavením vysoké zdi, snížením převýšených budov obývaných židy, zazděním či alespoň dočasným uzavřením oken židovských domů a krámů vedoucích směrem ke kostelům či cestám, po nichž se ubírala sváteční procesí. Moravský zemský archiv v Brně (dále MZA), B1 Gubernium (1048) 1613-1785/1790, sg. J 20/3, kart. 705.

4 Pěkný, Tomáš: Historie Židů v Čechách a na Moravě. Praha 2001, s. 95.

5 V této době, tzn. v letech 1726 až 1727, bylo v souvislosti s vydáním translokačního reskriptu vypracováno 
Myšlenka týkající se zásadního omezení počtu židovského obyvatelstva v zemi nebyla rozhodně nikterak nová a již vůbec nikterak neočekávatelná. Bylo jen otázkou času, kdy nejvyšší místa přikročí ke konkrétním restriktivním opatřením a uvedou je do praxe.

$\mathrm{S}$ více či méně intenzívními snahami o redukování počtu židovského obyvatelstva se setkáváme již na konci 17. století, jak již bylo zmíněno výše. Hlavní cíl těchto snah spočíval nejen v omezení, respektive v zastavení nárůstu židovského obyvatelstva, ale ideálně ve snížení jeho počtu jak ve městech, tak i na venkově. První návrhy na přijetí konkrétních opatření zazněly již na jednání zemského sněmu v roce 1650 . Nejradikálnější z nich požadoval vypovězení všech židů z míst, kde nebyli usazeni před 1. lednem 1618 a současně zásadní omezení jejich migračních možností. V předloženém návrhu se počítalo $\mathrm{s}$ tím, že se židé budou moci usazovat pouze $\mathrm{v}$ těch místech, kde pobývali nejpozději právě k uvedenému roku $1618 .{ }^{6} \mathrm{~K}$ realizaci návrhu v uvedené podobě sice až na výjimky nedošlo (především z důvodů finančních), jednání o omezení počtu židovského obyvatelstva a ruku v ruce s nimi o hospodářských dopadech tohoto rozhodnutí probíhala však téměř nepřetržitě i během následujících let. Jejich výsledkem bylo sice nakonec potvrzení uvedeného sněmovního usnesení Leopoldem I. v roce 1671, avšak v mírnější formě, jež spočívala v posunu hranice židovského osídlení k roku $1657 .{ }^{7} \mathrm{~V}$ praxi to znamenalo potvrzení jeho stávajícího rozsahu.

Předkládání dalších návrhů, jež se týkaly restriktivních opatření vưči židovskému obyvatelstvu, pokračovalo i v následujícím století, zvláště v průběhu dvacátých let. Na zasedání zemského sněmu v roce 1724 byl znovu předložen k projednání původní návrh na posunutí hranice vymezující rozsah židovského osídlení ke stavu z roku $1618 .{ }^{8}$ Ani tentokrát se jej však nepodařilo prosadit z důvodů prakticky totožných jako v době, kdy byl návrh předložen poprvé (1650), tzn. ekonomických, vycházejících především z opodstatněné obavy ze zásadního omezení př́ijmů plynoucích do státní pokladny z židovských daní. ${ }^{9}$ Definitivní rozhodnutí týkající se stanovení počtu židovského obyvatelstva v zemi se tak

několik desítek situačních plánů českých a moravských měst a městeček, na nichž byla vyznačena židovská obydlí. O okolnostech jejich vzniku a základní přehled v té době známých plánů z Čech viz Roubík, František: Plánky obcí v Čechách s vyznačením židovských obydlí z roku 1727 (se 14 plány). Časopis společnosti přátel starožitností českých 39, 1931, s. 49-68. Další mapy a plány jsou uloženy v NA, Sbírka map a plánů a ve fondech Českého gubernia. Základní informace o plánech moravských uložených ve sbírce map a plánů MZA v Brně jejich a přehled viz Frunc, Ondřej: Židovské ghetto na podkladech plánů z let 1727. Diplomová práce, Masarykova Univerzita v Brně, Filozofická fakulta - Historický ústav, Brno 2017. Ani zde se, obdobně jako v citovaném přehledu zpracovaném Františkem Roubíkem, nejedná o jejich úplný výčet, další plány jsou uloženy ve fondech velkostatků i gubernia. Nejnověji je translokačním plánům věnována obsáhlá publikace, přinášející zevrubnou analýzu všech dosud známých plánů uložených v NA, MZA a ZA v Opavě: Paulus, Filip - Steinová, Šárka a kol.: Krajina a urbanismus na rukopisných plánech z 18. století. Translokační plány židovských obydlí v zemích Koruny české v letech 1727-1728. Praha 2020.

6 Ebelová, Ivana - ̌̌ezníček, Michal - Woitschová, Klára - Woitsch, Jiří: Etnografický atlas Čech, Moravy a Slezska V. Židovské obyvatelstvo v Čechách v letech 1792-1794, Praha 2007, s. 11-12, 22-23.

7 Pěkný, T.: Historie Židů, s. 90.

8 Pěkný T.: Historie Židů, s. 94. NA, Sbírka patentů, č. 951, 952.

9 V letech 1723 a 1724 bylo zároveň přikročeno ke zjištování skutečného počtu židovského obyvatelstva žijícího na venkově, kdy se kromě toho měly zaznamenávat nejen rodiny usedlé $\mathrm{v}$ př́slušných lokalitách před 1 . lednem 1618, ale i rodiny usadivší se v konskribovaných lokalitách po tomto roce, a to jak s panovnickým souhlasem, tak i bez něho. Při zpracovávání jednotlivých soupisů se ukázala vzhledem k velkému časové- 
váže až k vydání familiantského zákona (na základě císařského reskriptu z 25. září 1726), na jehož základě byl určen tzv. numerus clausus. ${ }^{10}$ Podle něho měl činit maximální počet židovských rodin usazených v Čechách 8 541, na Moravě 5 106, ve Slezsku byla horní hranice počtu rodin upravena až patentem Marie Terezie ze 17. dubna 1752 na celkový počet 119 rodin (88 na Těšínsku, 23 na Opavsku a Krnovsku a 8 rodin ve Vidnavě). ${ }^{11}$

Počínaje dnem vydání familiantského zákona byli všichni ženatí či ovdovělí židé, kteří uzavřeli sňatek nejpozději v září 1726 považováni za hlavy rodiny (patres familias) a získali právo pobytu v zemi, tzv. inkolát. Uzavírat sňatek za života otce mohli od této chvíle pouze nejstarší synové (familiantské místo a s ním i právo pobytu v zemi mělo přecházet i v dalších generacích výhradně na prvorozené syny), ostatním bylo ponecháno na úvaze, zda se ožení a usadí za hranicemi (za předpokladu, že se tak dálo v souladu s právními normami dané země) či setrvají ve stávajícím místě, avšak s minimálním výhledem na možnost získání povolení k uzavření sňatku. Rodiny pouze s ženskými potomky pozbývaly podle nového zákona po smrti otce familiantské místo a byly automaticky považovány za vymřelé. Za uzavírání sňatků bez předchozího udělení svatebního konsensu, respektive za přestoupení nařízení familiantského zákona obecně, hrozily nemalé postihy, finančními pokutami počínaje, až po vypovězení provinilce ze země. ${ }^{12}$ Nesouhlas s obsahem zákona, jenž zásadně narušoval tradiční židovské principy rodinné hodnoty spojené se vstupem do manželství, se bezprostředně odrazil v nárůstu počtu sňatků uzavíraných z pohledu státní administrativy nelegálně, „pouze“ v souladu s židovskými normami a tradicemi. Na děti narozené z těchto svazků bylo z hlediska úředního pohlíženo jako na nemanželské.

Uvedený zásah do samotné podstaty rodinného života židů v důsledku vydání familiantského zákona byl zásadním, nikoli však jediným omezením ovlivňujícím přirozený populační růst židovského obyvatelstva, jež mělo bezprostřední dopad na velikost jednotlivých židovských komunit v Českých zemích. ${ }^{13}$

V takto striktně vymezené podobě platil familiantský zákon necelých pět let, do května 1731, kdy vyhlásili místodržící opatření, jež spočívalo v možnosti udělení dispensu k uzavírání sňatku panovníkem těm židům, na něž se dosud podle starších nařízení

mu odstupu nereálnost požadavku věrohodného zmapování židovského osídlení k roku 1618. NA, HBS, kart. 1-8.

10 Základní charakteristika familiantského zákona viz Cerman, Ivo: Familiants Law. In: The Yivo encyclopedia of Jews in Eastern Europe. Volume 1, New Haven 2008. s. 493-494 (on-line: https://yivoencyclopedia. org/article.aspx/Familiants_Laws; cit. 8. 10. 2020).

11 Scari, Hieronymus von: Systematische Darstellung der in Betreff Juden in Mähren und im k. k. Antheile Schlesiens erlassenen Gesetze und Verordnungen, Brünn 1835, s. 3.

12 NA, Sbírka patentů, Nr. 970.

13 Nesládková, Ludmila: Přrrozená reprodukce židovského obyvatelstva Moravy v éré familiantů. In: Židé a Morava: sborník příspěvků přednesených na konferenci konané 10. listopadu 1999 v Muzeu Kroměřížska. Kroměříž 1999 (vyd. 2000), s. 33-41; Králová, Michaela: Důsledky familiantského zákona na život jedné židovské rodiny v Pacově v letech 1726 až 1850. In: Vlastivědný sborník Pelhřimovska 14 (2003), s. 81-89; Fišer, Rudolf: Třebičtí familianti v proni polovině 19. století. Familiantský zákon v každodenním životě ghetta. In: Židé a Morava: sborník z konference konané v Muzeu Kroměřížska dne 14. listopadu 2007. Kroměříž 2007 (vyd. 2008), s. 7-20; Ebelová, Ivana: Das Familiantengesetz und die jüdische Bevölkerung in den böhmischen Ländern. In: Schätze der Welt aus landeshistorischer Perspektive. Festschrift zum 65. Geburtstag von Wolfgang Wüst, St. Ottilien 2018, s. 747-755. 
vztahoval zákaz vstupu do manželství. Při udělování výjimek se přihlíželo k ekonomickému postavení žadatele, nezanedbatelnou (nikoli však rozhodující) roli hrála výše odváděných daní. V každém případě však musela být dodržena zásada nepřekročení pevně stanoveného celkového počtu familiantů v zemi.

K další modifikaci stávajícího znění zákona došlo na základě dvorského dekretu z března 1734 v souvislosti se změnami v oblasti daňové. Rodina, respektive hlava rodiny, odvádějící daň vyšší než 700 zl., mohla žádat místodržitelství (od poloviny 18. století gubernium) o zvláštní udělení svatebního konsensu kromě prvorozeného syna ještě v pořadí dalším dvěma narozeným, familianti, jejichž kontribuce činila minimálně 500 zl., pro druhorozeného syna. Za získání povolení k uzavření sňatku se odváděly přesně určené taxy. Udělení svatebního konsensu však neznamenalo současné udělení inkolátu - ten získával zpravidla automaticky pouze prvorozený syn. Podle uvedeného dekretu tak bylo pražským židům tímto způsobem povoleno uzavření 40 sňatků, venkovskému židovstvu v rámci všech dvanácti krajů pak 84 sňatků. Ve výsledku to znamenalo, že na každý kraj připadalo sedm sňatků navíc. ${ }^{14}$

Zásadnější změna, vztahující se k familiantskému zákonu, konkrétně k celkovému počtu familiantských míst, je spojena až s reformními zásahy Josefa II. Celkový povolený počet židovských rodin v Českých zemích byl zvýšen o 353, takže pro Moravu vzrostl jejich počet v roce 1787 z původních 5106 na 5400 , žijících v 52 určených obcích, ${ }^{15}$ necelé dva roky poté byl dosavadní počet židovských rodin navýšen i v Čechách, a to z dosavadních 8541 na $8600 .^{16}$

\section{Nařizení provázející vydání familiantského zákona a udělování svateb- ních konsensů}

Obrat̉me nyní pozornost k jednotlivým typům písemností, jež souvisely s vydáním familiantského zákona (ale i s dalšími předpisy a nařízeními), především pak s nově zavedeným udělováním svatebních konsensů, a to na př́ikladu Čech. ${ }^{17}$

V souvislosti s přípravou restriktivních opatření vưči židovské populaci připadla významná úloha úvodem zmiňované židovské komisi, jež měla připravit podklady pro zjištění skutečného počtu židů žijících v zemi, včetně shromáždění informací týkajících se

14 Na základě dosud zpracovaných pramenů a především vzhledem $\mathrm{k}$ tomu, že velká část bezprostředně souvisejících písemností vzala za své při požáru vídeňského justičního paláce na počátku dvacátých let minulého století nelze potvrdit, ale ani vyvrátit, zda bylo uvedené navýšení skutečně realizováno. Zdá se však, s ohledem ke statistickým údajům z mladšího období, že šlo patrně jen o přechodný stav. Österreichisches Staatsarchiv, Allgemeines Verwaltungsarchiv Wien, Hofkanzlei (dále ÖStA/AVA) - Dekrete, sg. IV.T.8., kart. 1545. Podrobněji viz Ebelová, I. a kol.: Etnografický atlas Čech, Moravy a Slezska V., 24-25.

15 17. listopad 1787. NA, Sbírka patentů, č. 2149.

16 3. duben 1789. NA, Sbírka patentů, č. 2169.

17 Pokud jde o Moravu, byla situace v mnohém analogická, geografické omezení pouze na Čechy je dáno několika faktory. Především působením židovské komise, jejíž činnost se nevztahovala na oblast Moravy ani Slezska, a dále pramennou základnou, především soupisy židovských familiantů a židovských rodin, které máme k dispozici pro období bezmála sta let pouze pro Čechy. 


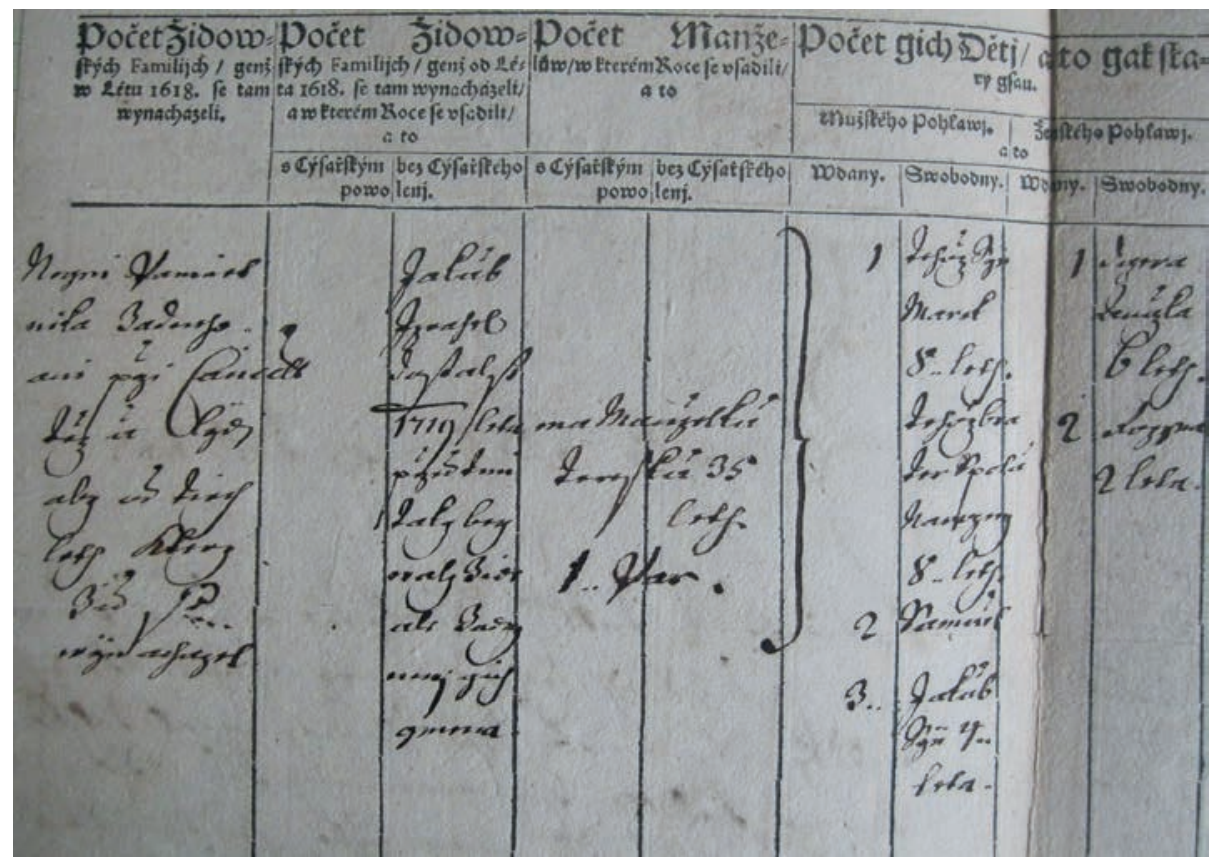

Obr. 2: Soupis židovských rodin z let 1723/1724 - výřez (NA, HBS, Chrudimsko, kart. 2)

způsobu jejich obživy a spolu s údaji o výši jimi odváděné kontribuce. Na konci roku 1723 (s pokračováním v roce následujícím) tak bylo přikročeno ke zpracování soupisu venkovského židovského obyvatelstva, v roce 1729 následovalo sčítání pražských židů. ${ }^{18}$

Další soupisy obdobného charakteru byly zpracovávány i v letech následujících, ${ }^{19}$ a to až do roku 1811, k němuž se váže poslední soupis této řady, vyhotovený jak pro venkovské, tak i pražské židovské obyvatelstvo (stejně jako i u konskripcí z roku 1793). ${ }^{20}$

Účel jednotlivých soupisů spočíval především v evidenci židovských rodin, respektive familiantů, cílem bylo kromě celé řady aspektů (včetně evidence výše daňového zatížení) současně i získání přehledu o rozsahu židovského osídlení a jeho případných proměnách. Jednotlivé soupisy představovaly zároveň i určitou formu dohledu či přesněji kontroly udělených familiantských míst, povolení k pobytu a s tím souvisejících udílení svatebních konsensů. ${ }^{21}$

18 Prokeš Jaroslav: Soupis pražských židů z roku 1729. Ročenka společnosti pro dějiny židů v Československé republice IV, Praha 1932, s. 308-342.

19 Ebelová, Ivana a kol., Soupis židovských familianti̊ v Čechách z roku 1783 - I. Národní archiv, Praha 2008,395 s.; táž, Soupis židovských familiantů v Čechách z roku 1783 - II. Národní archiv, Praha 2010, 410 s.; táž, Soupis židovských familiantư v Čechách z roku 1783. Generální rejstř́íky. Národní archiv, Praha 2010, 98 s.

20 Ebelová, Ivana: Census Lists of Jewish Families in Bohemia, 1723/1724-1811. Judaica Bohemiae XLVIII-1, Jewish Museum in Prague 2013, s. 79-91.

21 Podrobně k jednotlivým soupisům a jejich struktuře viz Ebelová, I. a kol.: Etnografický atlas Čech, Moravy a Slezska V., 33-46. 


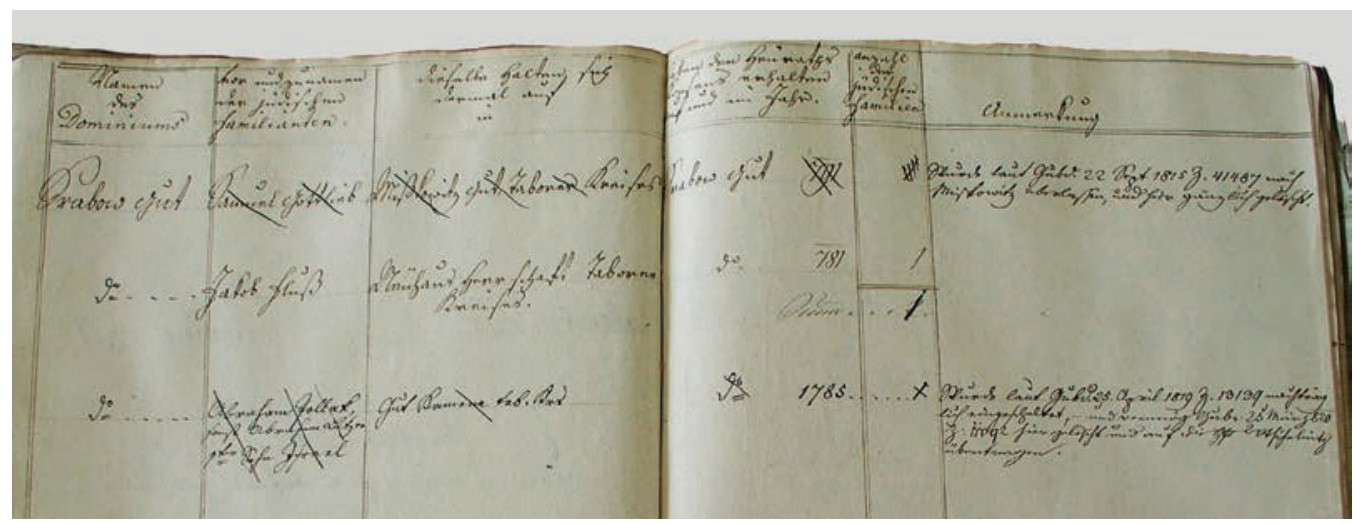

Obr. 3: Soupis z roku 1799, z jehož struktury analogicky vycházejí soupisy venkovského židovského obyvatelstva i pražských židů z roku 1811 (NA, HBS, kart. 27, kn. 5)

Konskripce byly vyhotovovány na předepsaných či předtištěných formulářích pro všechny kraje podle aktuálního správního členění. Jejich rozesílání zajištovala židovská komise prostřednictvím krajských hejtmanů, kteří je dále distribuovali do jednotlivých měst a na panství, kde proběhlo jejich vyplnění určenými osobami, správci nebo úředníky jednotlivých panství (ředitel, administrátor, purkrabí či vrchní), ve městech městskými úředníky. Správnost zaznamenaných údajů stvrzovali jejich vyhotovitelé vlastnoručním podpisem s uvedením data a místa vyhotovení, nezřídka je připojena i přitištěná pečet. $\mathrm{V}$ některých lokalitách se na vyhotovení soupisu podíleli přímo představitelé židovské obce - svou účast stvrzovali svými podpisy. Formuláře pro nejstarší soupisy venkovských židů z let 1723 a 1724, tzn. z doby bezprostředně předcházející vydání familiantského zákona, byly vyhotoveny a následně i vyplněny variantně v jazykově české či německé verzi v závislosti na jazyku užívaném primárně v dané oblasti či jazyku zapisovatele. Předepsané rubriky byly formulovány podle konkrétního hlavního účelu, k němuž byl daný soupis vyhotovován (osídlení, informace, zda jmenovanému byl udělen souhlas panovníka k pobytu v dané lokalitě či nikoli, profese, výše odváděných daní apod.). ${ }^{22}$ Vyplněné formuláře byly poté odesílány zpět na příslušné krajské úřady, kde byly podrobeny důkladné kontrole, ověřovaly se zvláště početní údaje, poté se postupovaly židovské komisi, po jejím zrušení v roce 1781 (de facto 1783) guberniu, formuláře nejmladších soupisů z let 1799 a 1811 státní účtárně.

Přestože byl familiantský zákon vydán v roce 1726, prováděcí předpis, řečeno dnešní terminologií, tedy jakým způsobem a za jakých podmínek mohou být žádosti o udělení svatebního konsensu nejen podávány, ale především schvalovány, byl vydán až na základě reskriptu z 1. června $1734 .{ }^{23}$ Pro vstup do manželství byla stanovena hranice minimálního věku snoubenců, jež činila u ženicha 18 a u nevěsty 15 let, zároveň bylo nařízeno vedení knih obřízek (označovaných jako knihy mohelo̊) pro evidenci narozených chlapců a knih

22 Tamtéž.

23 ÖStA/AVA, Hofkanzlei - Dekrete, sg. IV.T.8, kart. 1545. 
narozených dívek. Současně se záznamem do př́slušné knihy bylo ve velmi jednoduché formě vystavováno mohelem potvrzení o provedené obřízce. ${ }^{24}$ Knihy mohelů či narozených dívek měly sloužit $\mathrm{v}$ případě potřeby $\mathrm{k}$ ověřování věku snoubenců (vedení židovských matrik bylo nařizeno až v roce 1784). Pokud nebyla daná informace nikde zaznamenána, bylo při posuzování žádosti o udělení souhlasu k uzavření sňatku požadováno dobrozdání dvou křestanských sousedů. Jednotlivé vrchnosti současně zodpovídaly za dodržení povoleného počtu židovských rodin usazených v konkrétních lokalitách v rámci jejich panství.

Ne nepodstatnou roli při rozhodování o udělení svatebního konsensu hrálo ekonomické postavení žadatele, výše jeho majetku, od něhož se odvozovala částka odváděné kontribuce. Na tento aspekt byl brán zvláštní zřetel zejména při schvalování žádostí týkajících se povolení uzavření sňatku pro v pořadí druhorozené a další syny, jak již bylo naznačeno výše. $V$ praxi to znamenalo, že žadatel musel disponovat dostatečným majetkovým zázemím, provozovat řemeslo, živnost nebo obchod v takovém rozsahu, aby byl bez větších problémů schopen uživit sebe i celou rodinu, a kromě toho řádně platil vyměřené daně. ${ }^{25}$ Pokud byly majetkové poměry žadatele tak nepříznivé, že odváděl kontribuci pouze v minimální výši, nemusel být (a zpravidla ani nebyl) žadateli svatební konsens udělen. $\mathrm{V}$ těchto př́padech bylo při schvalování povolení otáleno i ve zdánlivě jasných př́padech (prvorozený syn, vdovec). Povolování sňatků na základě majetkových poměrů žadatele bylo zcela zjevně vedeno snahou o maximální možnou eliminaci ekonomicky slabého židovského obyvatelstva ve prospěch movitějších souvěrců, jimiž odváděné daně byly vítaným zdrojem příjmů do státní pokladny, naopak na sociálně slabší obyvatele bylo pohlíženo jako na potenciální přítěž. ${ }^{26}$ I přesto však v zásadě zůstávalo nadále primárním hlediskem, že souhlas př́ślušných míst s uzavřením sňatku mohl být udělen pouze po uvolnění familiantského místa a tedy nepřekročení celkového stanoveného počtu rodin. K získání místa tak mohlo dojít v zásadě trojím způsobem:

- úmrtím familianta, což byla nejobvyklejší a nejméně problematická varianta;

- odchodem stávajícího familianta do zahraničí (z obavy z krácení př́ijmů odváděných do státní pokladny skládali odcházející židé před svým odchodem tzv. Abfahrtsgebühr, tedy poplatek, jehož výše měla odpovídat hodnotě majetku odváženého do nového místa pobytu); ${ }^{27}$

- dobrovolným postoupením familiantského místa. V tomto případě se tak dělo nejčastěji z otce na prvorozeného syna, $v$ ostatních př́padech nesměl při převodu familiantského

24 Zlomek těchto potvrzení je uložen v Archivu židovského muzea.

25 Singer, Ludwig: Zur Geschichte der Juden in Böhmen in den letzten Jahren Josefs II. und unter Leopold II. I. Joseph Anton von Riegger und die Judenfrage. II. Um neue Judenordnung und Judenbesteuerung. III. Die Gegner der Juden. Ročenka Společnosti pro dějiny židů v Československé republice VI, 1934, s. $189-280$.

26 Na základě reskriptu 22. března 1749 byla provedena další úprava finančních povinností žadatelů o udělení povolení k uzavření sňatku, odvíjející se od rozdělení židovského obyvatelstva do pěti majetkových tř́íd podle výše odváděné kontribuce. ÖStA/AVA, Hofkanzlei - Dekrete, sg. IV.T.8., kart. 1545. Podrobněji viz Ebelová, I. a kol.: Etnografický atlas Čech, Moravy a Slezska V., 25.

27 Počínaje rokem 1786 mohli ti židé, jejichž majetek nepřesahoval hodnotu vyšší než 200 zl., získat na základě žádosti povolení $\mathrm{k}$ vystěhování bez povinnosti hradit jakékoli další poplatky (vydavatelem bylo $\mathrm{v}$ těchto př́padech gubernium). 
místa z jedné osoby na jinou chybět doklad, jímž původní familiant potvrzoval absenci mužských potomků.

Vydávání dalších upřesňujících ustanovení vycházejících z familiantského zákona neustalo ani v průběhu následujících let. Jejich obsah se týkal především precizace související s posuzováním a schvalováním jednotlivých žádostí, s jejich evidencí a s postihy za porušení předpisů.

O uzavřených sňatcích byla vedena přesná evidence. Počínaje rokem 1765 náležela do kompetence vrchnosti nebo magistrátu toho místa, pod jehož ochranu spadala osoba vstupující do manželství. Společně s údajem o uzavření sňatku měly být poznamenávány rovněž údaje o výši majetku ženicha a nevěsty, uvedena informace o stávajícím nebo budoucím způsobu obživy. Za správné, oprávněné vyhotovení dokladu o uzavření sňatku ručili počínaje rokem 1766 jednotliví vrchnostenští a magistrátní úředníci svým majetkem, každé neoprávněně vydané potvrzení mělo být trestáno citelným finančním postihem. ${ }^{28}$ Součástí evidence byly jednotlivými vrchnostenskými úřady a magistráty každoročně vypracovávané sumární tabulkové přehledy o počtu vydaných svatebních konsensů. Ty byly odesílány českému, na Moravě moravskému zemskému guberniu.

Jak bylo již připomenuto výše, další nařízení vztahující se k židovskému obyvatelstvu, související s žádostmi o uzavření sňatku, jejich vyřizováním i evidencí, se váží $\mathrm{k}$ vládě Josefa II. Nešlo jen o zmíněné zvýšení počtu familiantských míst v roce 1787, ale především o nařízení spadající do panovníkova modelu vytvoření jednotné, na centralistických principech vybudované státní správy. V rámci uvedených opatření bylo v souvislosti s reflektovaným tématem vydáno dvorským dekretem z 20. února 1784 nařízení o vedení židovských matrik. ${ }^{29}$ Dva roky poté následovalo rozšiření všeobecných podmínek týkajících se povolování sňatků o zákaz udělovat souhlas těm žadatelům, kteří neabsolvovali povinnou školní docházku (na základě dvorského výnosu z 15. dubna 1786). Její absolvování bylo nezbytné doložit písemným potvrzením, zároveň měl žadatel prokázat i aktivní znalost němčiny jako zemského jazyka. ${ }^{30}$ Od roku 1787 , kdy byl spojenou česko-rakouskou dvorskou kanceláří přijat návrh českého zemského gubernia na přijetí stálých osobních a rodinných jmen židovským obyvatelstvem (obdobně jako bylo již dříve zavedeno u většinového křestanského obyvatelstva), náleželo k povinnostem žadatelů o udělení svatebního konsensu předložení dokladu o stávajícím i původním jménu; stejné údaje měly být uvedeny i u snoubenky. ${ }^{31}$

28 Sammlung aller k. k. Verordnungen und Gesetze vom Jahre 1740 bis 1780 in einer chronologischen Ordnung und sistematischen Verbindung V, Wien 1786, č. 889, s. 162-163; tamtéž, č. 993, s. 259.

29 Jaksch, Karl Peter: Gesetzlexikon im Geistlichen, Religions - und Toleranzsache wie auch in Güter-, Stiftungs-, Studien- und Zensursachen für das Königreich Böhmen von 1601 bis Ende 1800, IV, Prag 1828, s. 127.

30 ÖStA/AVA, Hofkanzlei - Dekrete, sg. IV.T.8., kart. 1545; Handbuch aller unter der Regierung des Kaisers Joseph des II. für die k. k. Erbländer ergangenen Verordnungen und Gesetze in einer sistematischen Verbindung, enthält die Verordnungen und Gesetze vom Jahre 1786, X, Wien 1788, s. 579; tamtéž, XI, s. 512. Podle dvorského dekretu z 27. ledna 1792 bylo předložení dokladu o absolvování školní docházky požadováno i od nevěsty, viz Sammlung der Gesetze, welche unter der glorreichsten Regierung des König Leopold des II. in den sammentlichen k. Erbländern erschienen sind in einer chronologischer Ordnung IV, Wien 1791, s. 27.

31 Patent z 25. října 1787. NA, Sbírka patentů č. 2140; Cirkuláře a vyhlášky (dále CV), i. č. 933 , kart. 15. S platností od 1. ledna 1788 měli všichni židovští obyvatelé dědičných rakouských zemí přijmout stálá 


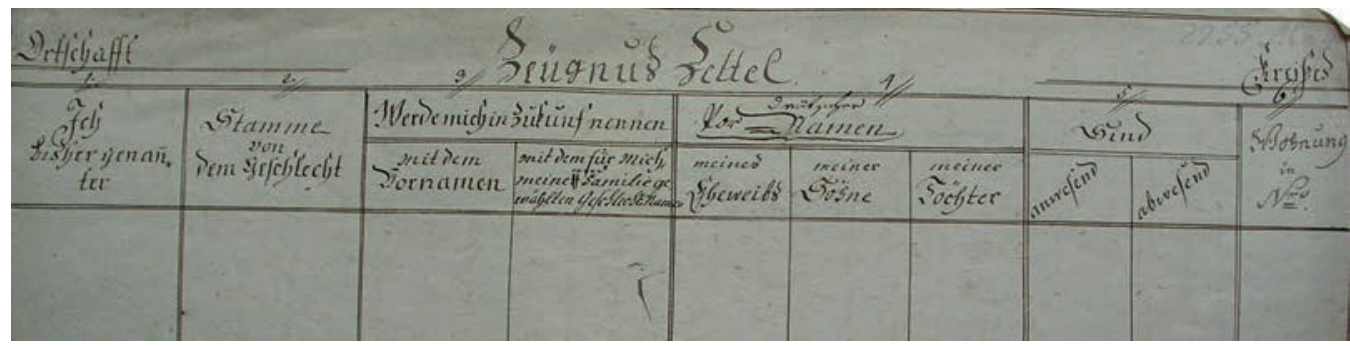

Obr. 4: Osvědčení o nových jménech přijatých židy 1787 (Zeugnisszettel). Formuláře byly rozesílány prostřednictvím krajských úřadů do měst a na panství s židovským obyvatelstvem. Vyplňováním byl za každou rodinu (včetně osob v závislém služebném postavení) pověřen otec jako hlava rodiny, př́padně poručník či svobodný muž. Ti zodpovídali za ráané vyplnění, což stvrzovali vlastnoručním podpisem, svůj podpis připojoval i zástupce příslušné židovské obce (SOA Třeboň, Velkostatek Strakonice 1575-1949, i. č. 744, sg. A-XI-4, kart. 26)

Všechny zmíněné doklady, jež byly součástí žádosti o udělení svatebního konsensu, zasílali žadatelé př́íslušnému krajskému úřadu, který vedl přehled o celkovém počtu sňatků povolených nejen v rámci daného kraje, jejich počet byl přesně určen i pro jednotlivé lokality. Krajští úředníci tak působili nejen v roli jakýchsi prostředníků mezi žadatelem a guberniem, od konce 18. století pak státní účtárnou, ale byli současně pověřeni kontrolou dodržování stanoveného počtu familiantských míst, tedy i udílení svatebních konsensů. Exaktním vymezením podmínek, co nejpřesnějším formulováním jednotlivých zákonných opatření se mělo maximálně předejít možným nesrovnalostem a nedorozuměním vyplývajícím z případného chybného výkladu at již dílčích ustanovení či nařízení jako celku.

Poslední úpravy nařízení se váží k roku 1797 v souvislosti s vydáním systemálního patentu, v jehož rámci byly kromě jiného sumarizovány právě i veškeré změny týkající se povolování a uzavírání sňatků mezi židovskou populací. ${ }^{32}$ Konec nejen těchto restriktivních opatření, ale i celé řady dalších, přinesl rok 1848, jenž znamenal pro židovské obyvatelstvo počátek zrovnoprávnění s křestanským obyvatelstvem, období emancipace.

\section{Svatební konsensy a jejich udílení}

Jakkoli by se mohlo zdát, že proces udílení svatebních konsensů byl poměrně jednoduchou záležitostí, zvláště byla-li nastavena určitá formální pravidla, o nichž bylo základně

př́íjmení a rodná jména., jejich seznam byl součástí citovaného patentu. Ten byl vzápětí rozšířen o další jména a termín přijetí nových jmen prodloužen do poloviny ledna. NA, CV, i. č. 946, kart. 15. Více viz Žáček, Václav: Studie $k$ vývoji židovských jmen osobnich v nové době. Ročenka Společnosti pro dějiny židů v Československé republice VIII, Praha 1936, s. 275-349.

32 Singer, Ludwig: Die Entstehung des Juden-Systemalpatentes von 1797. Ročenka Společnosti pro dějiny židů v Československé republice VII, 1935, s. 191-255. 
pojednáno výše, opak je pravdou. Základní předpoklad podání žádosti o udělení souhlasu k uzavření sňatku spočíval ve splnění stanovených podmínek a formalit. Na počátku celého procesu stálo vyhotovení žádosti o udělení souhlasu s uzavřením sňatku adresované přrislušnému krajskému úřadu. Nezbytnou součástí byly informace týkající se profese žadatele, prohlášení, že nemá žádného ženatého bratra. Krajský úřad posuzoval žádost v první instanci, přičemž rozhodující bylo nejen nepřekročení stanoveného limitu židovských familiantů v rámci daného panství a tedy i daného kraje, ale i schopnost unést daňové zatížení, jemuž bylo židovské obyvatelstvo vystaveno. V dalším kroku byla žádost postoupena kamerálnímu oddělení gubernia. Pokud se nejednalo o komplikované případy, byly jednotlivé žádosti vyřizovány kladně. Žel v těchto případech, jichž byla většina, není původní žádost k dispozici, stejně tak nedisponujeme konečným rozhodnutím (v obou případech došlo v 19. století k jejich plošné skartaci). Jedinou evidenci tak představuje záznam v podacích protokolech, z něhož se dovídáme kdo, kdy a na kterém panství žádal

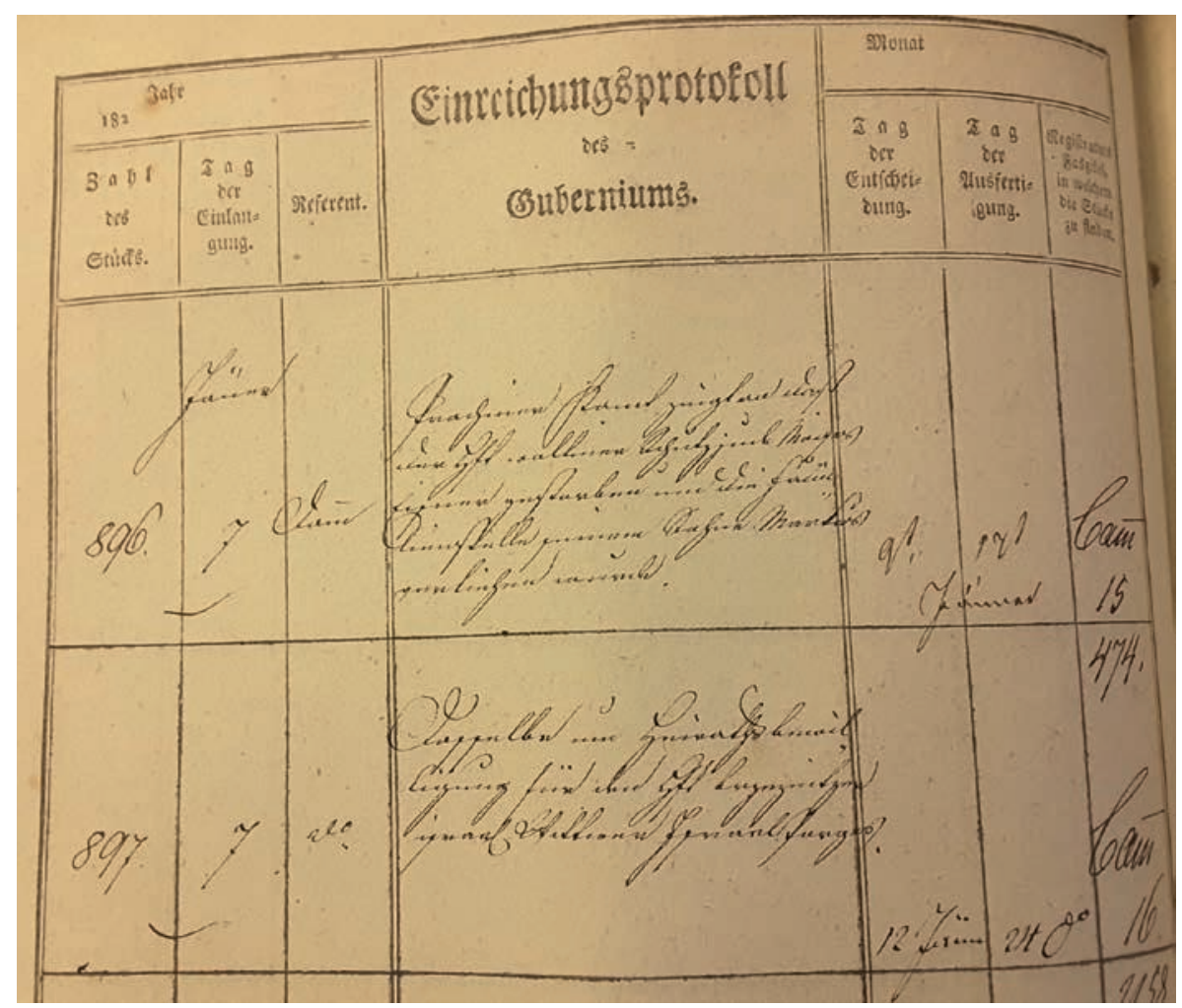

Obr. 5: Podací protokol z roku 1821 se záznamem týkajícím se uvolnění familiantského místa ve Volyni v Prácheňském kraji v důsledku úmrtí stávajícího familianta Moisese Eisnera a jeho převedení na syna Markuse; druhý záznam se týká žádosti o udělení svatebního konsensu březnickému ovdovělému židu Israelu Porgesovi, kterou postoupil krajský úřad Prácheňského kraje (NA, České gubernium (dále ČG) - pomocné knihy 1821) 

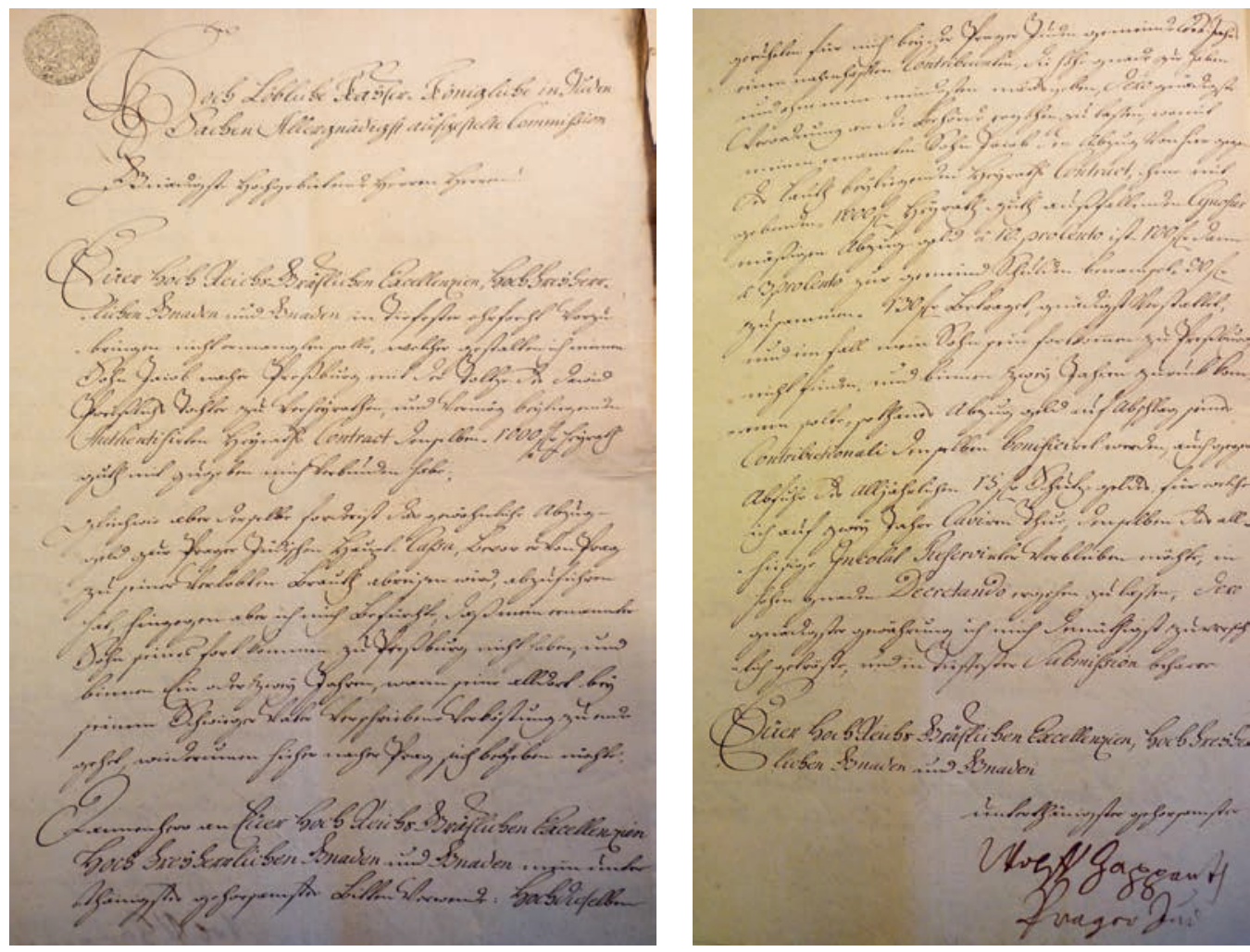

Obr. 6a, b: Přepis žádosti pražského žida Wolfa Zapperta z roku 1770, adresované pražským židovským starším, ohledně refundace financí - Heiratsgut - složených při přiležitosti sňatku jeho syna do zahraničí a př́padného návratu během následujících dvou let (NA, ČG - camerale, kart. 213)

o udělení povolení k uzavření sňatku, kdy daná žádost došla, kdy bylo vydáno rozhodnutí a vyhotovena odpověd'.

Ne vždy však bylo vyřizování žádostí spojených s udílením svatebního konsensu tak bezproblémové a přímočaré. $\mathrm{V}$ těchto případech se postupovalo zcela individuálně, celý proces vyřízení dané žádosti probíhal zpravidla v delší časové lhưtě, za spoluúčasti příslušné vrchnosti. Se specifickou situací se setkáváme pak v Praze, a to v souvislosti se zapojením starších tamní židovské obce.

Jakým způsobem a nakolik byli jednotliví aktéři zapojeni do celého procesu řešení zvláště problematických případů, tak vycházelo z jejich obsahu, kdy byla více či méně prakticky aplikována jednotlivá nařízení a předpisy, což se přirozeně odráží v celém úředním procesu a v písemnostech jej provázejících. 


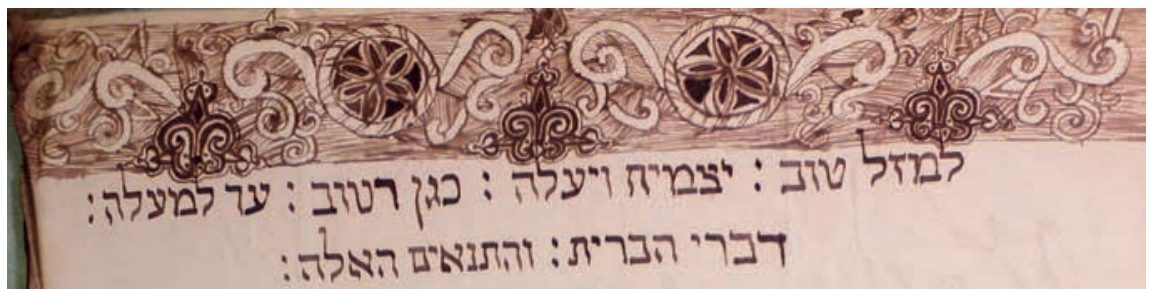

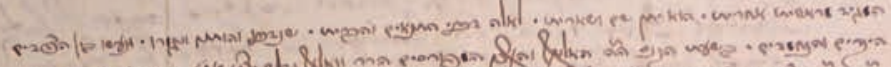

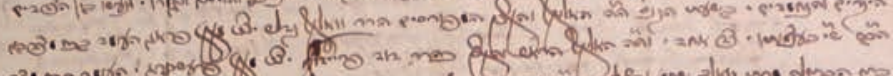

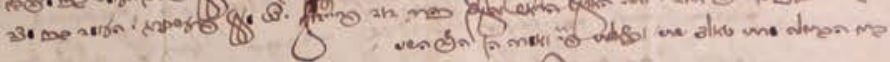

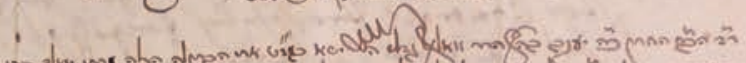

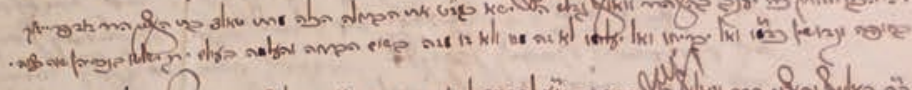

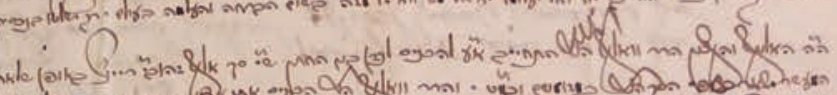

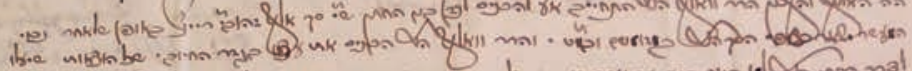

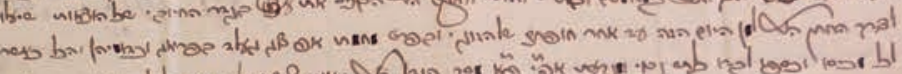

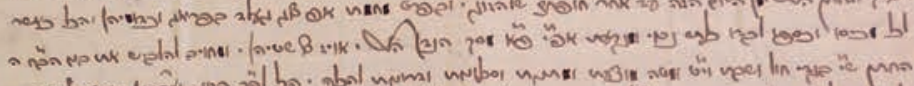

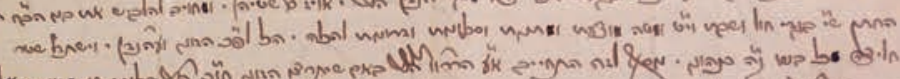

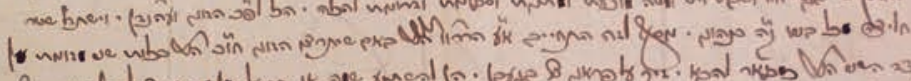

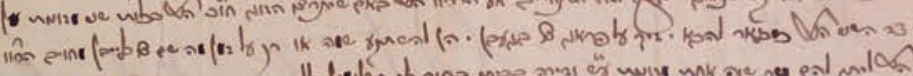

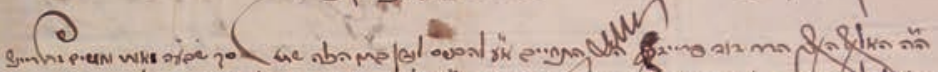

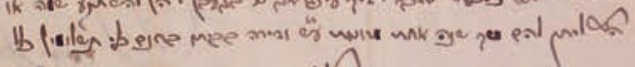

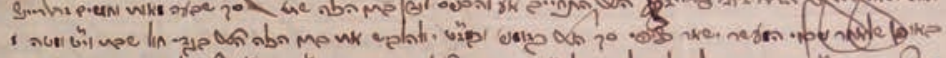

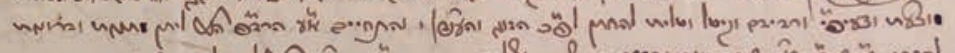

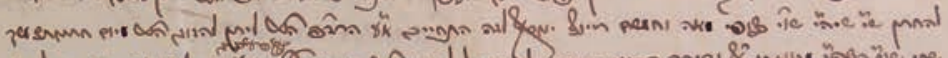

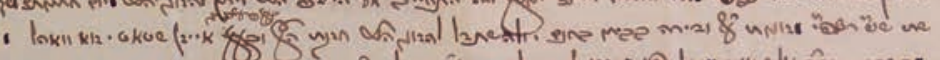

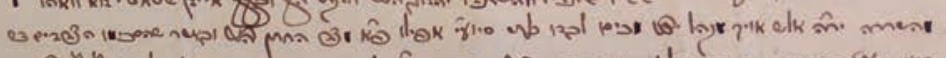

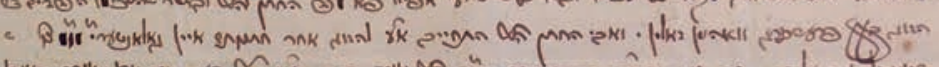

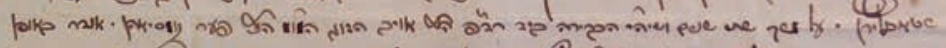

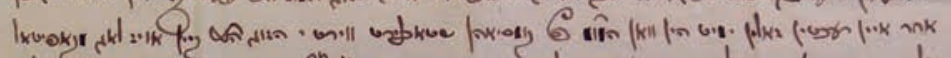

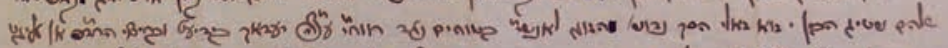

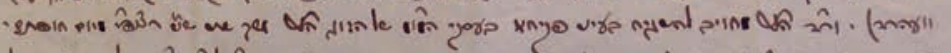

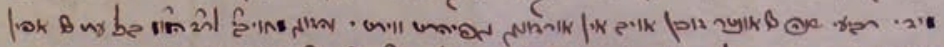

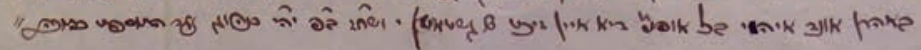

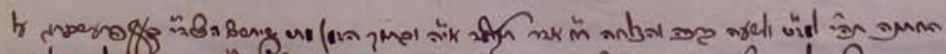

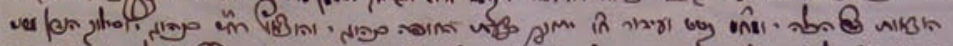

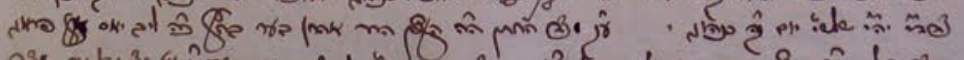

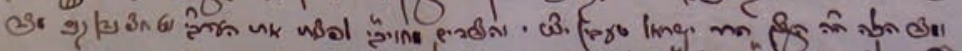
lion Gafin b liver my

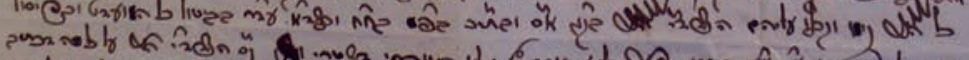

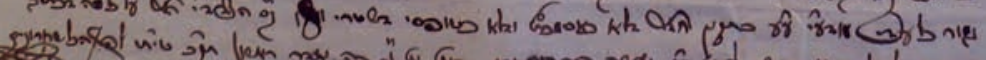
हु.

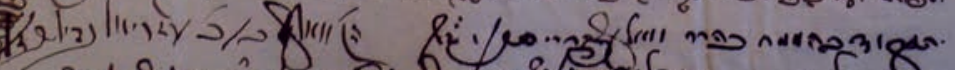

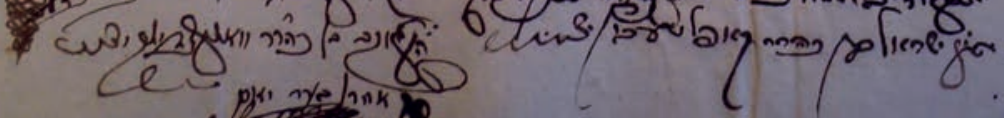

Obr. 7: Originál žádosti Wolfa Zapperta (NA, ČG - camerale, kart. 213) 

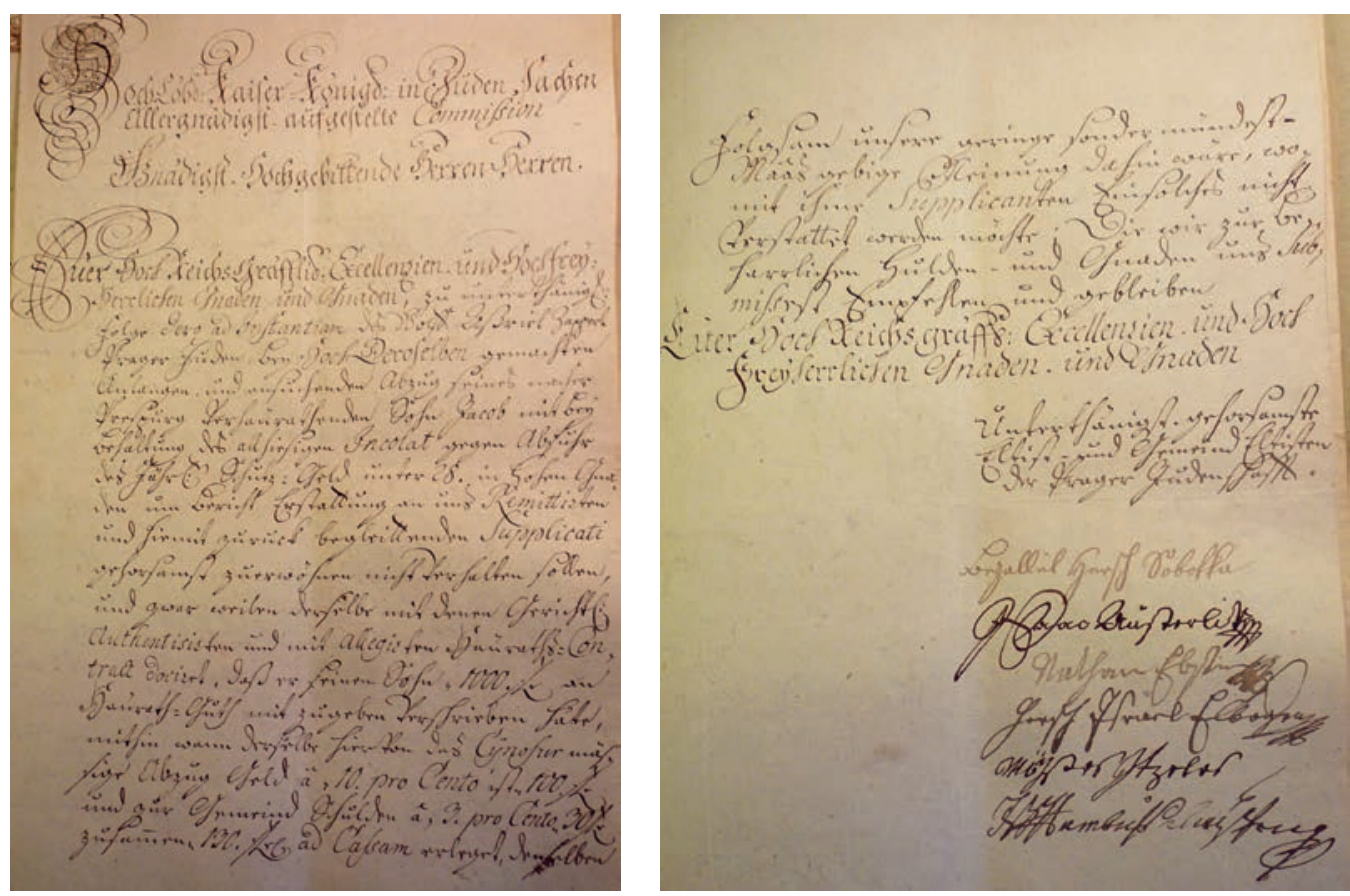

Obr. 8a, b: Vyjádření pražských židovských starších k žádosti Wolfa Zapperta (zkráceno) (NA, ČG - camerale, kart. 213)

\section{Závěr}

Shrneme-li na závěr výše uvedené poznatky, vstupovala do procesu vyřizování svatebních konsensů od vydání familiantského zákona v roce 1726 až do roku 1848 řada subjektů. Na jedné straně poměrně širokého spektra přímých účastníků to byla především osoba žadatele, na straně druhé, tedy těch, v jejichž rukou spočívalo rozhodnutí o úspěchu či neúspěchu konkrétního podání pak jednotlivé úřady od městských a vrchnostenských, přes krajské až po židovskou komisi (1714, od roku 1749 jako instituce přičleněná k reprezentaci a komoře a od roku 1763 k českému guberniu, u něhož působila až do svého zrušení o necelá dvě desetiletí později), po zrušení židovské komise v roce 1781, resp. 1783 (de jure a de facto) gubernium (do roku 1849), poté místodržitelství, státní účtárna. Panovník se zapojoval do celého procesu schvalování žádostí pouze ve výjimečných případech (s konkrétními případy, kdy je doložen jeho osobní podíl, se setkáváme spíše až v souvislosti s Josefem II.). 


\section{Familiant Law and its impact on the granting of wedding permission in Bohemia}

From 1726 until 1848, the primary regulation that directly influenced the life of the Jewish population in the Czech lands was the Familiant Law, which was followed by or, more precisely, accompanied by the issuance of the so-called translocation rescript in 1727. Both of these legal regulations had a fundamental influence on the structure of Jewish settlement and the number of Jewish inhabitants and families in the Czech lands. The paper is devoted to the application processing procedure for the granting of wedding permission to the Jewish population after the issuance of the Familiant Law, using Bohemian example. The whole process was in the competence of the Jewish Commission (in Bohemia) established in 1714 in connection with attempts to restrict the Jewish population. Since 1749, the Commission was institutionally affiliated to the representation and chamber. From 1763 it came under the Bohemian governorate, where it operated until its abolition less than two decades later by the court decree of 31 December 1781 de jure and in 1783 also de facto. Upon the issuance of the Familiant Law in 1726 and up until 1848, numerous entities were engaged the process of granting wedding permission. On the one hand, it was primarily the individual applicant, and on the other, those in whose hands rested the decision on the success or failure of a particular submission, i.e., the individual authorities of the city and manorial nobility, regional bodies, the Bohemian governorate (Moravian governorate in Moravia by analogy), the governor's office, the state accounting office and finally the Jewish Commission. The whole approval procedure is documented with examples of individual documents (from the submission of the application to its conclusion). 